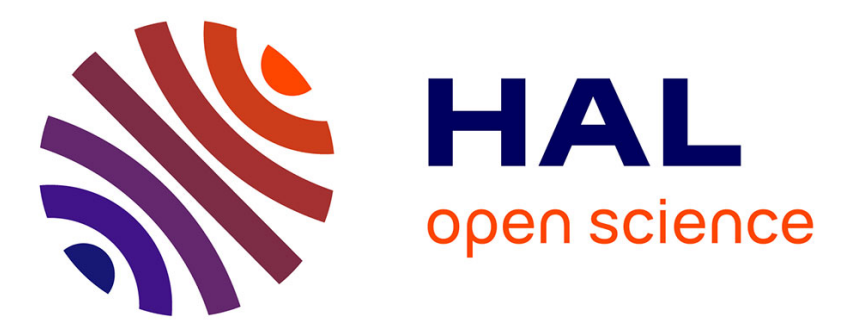

\title{
Cloning and expression of human 5-HT4S receptors. Effect of receptor density on their coupling to adenylyl cyclase
}

Sylvie Claeysen, Patrick Faye, Michèle Sebben, Stéphanie Barrère-Lemaire, Joël Bockaert, Aline Dumuis

\section{To cite this version:}

Sylvie Claeysen, Patrick Faye, Michèle Sebben, Stéphanie Barrère-Lemaire, Joël Bockaert, et al.. Cloning and expression of human 5-HT4S receptors. Effect of receptor density on their coupling to adenylyl cyclase. NeuroReport, 1997, 8 (15), pp.3189-3196. 10.1097/00001756-199710200-00002 . hal-02491123

\section{HAL Id: hal-02491123 \\ https://hal.science/hal-02491123}

Submitted on 25 Feb 2020

HAL is a multi-disciplinary open access archive for the deposit and dissemination of scientific research documents, whether they are published or not. The documents may come from teaching and research institutions in France or abroad, or from public or private research centers.
L'archive ouverte pluridisciplinaire HAL, est destinée au dépôt et à la diffusion de documents scientifiques de niveau recherche, publiés ou non, émanant des établissements d'enseignement et de recherche français ou étrangers, des laboratoires publics ou privés. 


\title{
Cloning and expression of human $5-\mathrm{HT}_{4 \mathrm{~S}}$ receptors. Effect of receptor density on their coupling to adenylyl cyclase
}

Sylvie Claeysen ${ }^{1}$, Patrick Faye ${ }^{1}$, Michèle Sebben ${ }^{1}$, Stéphanie Lemaire ${ }^{2}$, Joël Bockaert ${ }^{1}{ }^{*}$, Aline Dumuis $^{1}$

${ }^{1}$ CNRS UPR 9023, Centre CNRS-INSERM de Pharmacologie-Endocrinologie (CCIPE), 141 rue de la Cardonille, 34094 Montpellier cedex 05

${ }^{2}$ CRBM du CNRS, UPR 9008, INSERM U.249, 1919 route de Mende, BP 5051, 34033 Montpellier Cedex 1, France

${ }^{*}$ Corresponding Author

\begin{abstract}
We have isolated a cDNA encoding the $5-\mathrm{HT}_{4 \mathrm{~S}}$ receptor by RT-PCR on poly $(\mathrm{A})^{+} \mathrm{RNA}$ from both human heart and brain. The sequence homology with the rat and mouse 5- $\mathrm{HT}_{4}$ receptors was high: $93.8 \%$ of identity in the amino acid sequence. None of the 24 amino acid substitutions observed between rat and human receptors are at positions likely to modify their pharmacology. Comparing the pharmacological properties of six agonists and five antagonists on rat and human $5-\mathrm{HT}_{4 \mathrm{~S}}$ receptors revealed no significant differences. We have analyzed the behavior of renzapride, a full and a partial agonist on mouse colliculi neurons and human heart biological responses respectively. The coupling efficiency of renzapride was two-fold lower than that of 5-HT for the stimulation of 5-HT4s receptors transfected in two different cell lines (LLC-PK1 and COS-7), but increasing the receptor density suppressed the partial agonist effect of renzapride.
\end{abstract}

Key words: Coupling efficiency; Human 5- $\mathrm{HT}_{4}$ receptor; Receptor density 


\section{INTRODUCTION}

$5-\mathrm{HT}_{4}$ receptors were first characterized in $1988 .{ }^{1}$ Since then they have been demonstrated in a wide variety of tissues in different species including, rodent, porcine, and human brain, guinea-pig ileum and colon, rat oesophagus, frog and human adrenocortical cells, human urinary bladder, human and porcine heart. ${ }^{2,3}$ The newly proposed pathophysiological properties of 5-HT4 receptors, both in the central nervous system (increase in olfactory and spatial memory ${ }^{2,4,5}$ ) and at the periphery (implication in arrhythmia and irritable bowel syndrome ${ }^{6}$ ), have stimulated investigations into a large series of selective and potent agonists and antagonists. ${ }^{2}$ These can now be tested for their putative therapeutic use. However, due to the difficulties encountered until now in cloning 5 - $\mathrm{HT}_{4}$ receptors, ${ }^{7,8}$ most of these drugs have been tested on functional animal preparations. In human heart and many other preparations, benzamides have been shown to be weak partial agonists whereas they are full agonists in mouse colliculi neurons. ${ }^{9-11}$ In the present study we addressed two questions: is there any species difference in 5- $\mathrm{HT}_{4}$ receptor pharmacology; and are the differences in efficacies reported for benzamides in different species due to a difference in coupling efficiency or to receptor structure? To answer these questions we cloned the human 5 - $\mathrm{HT}_{4}$ receptor from heart and brain and analyzed their molecular pharmacological properties.

\section{MATERIALS AND METHODS}

\section{Isolation and sequencing of a human heart and brain 5-HT 4 cDNA by RT-PCR}

Total RNA was isolated from the atrium of a patient undergoing heart transplantation. Poly $(\mathrm{A})^{+}$RNA was extracted using Dynabeads Oligo (dT) ${ }_{25}$ (Dynal) and reverse transcribed using Superscript II RNAse H reverse transcriptase (Life Technologies) and random nonamers. RT-PCR was performed with the following oligonucleotides designed on International Patent WO 94/14957, ON1 (Sequence 7, position 5-27): 5'-TAATGGACAAACTTGATGCTAATG3' and ON2 (Sequence 14, position 765-786): 5'-TCAGAAGCATGATTCCAGGGAT-3'. These primers are located in the $5^{\prime}$ and $3^{\prime}$ translated regions of the $5-\mathrm{HT}_{4 \mathrm{~S}}$ receptor. PCR was performed with the Taq DNA Polymerase (Eurobio) with a cycle of $94^{\circ} \mathrm{C}$ for $3 \mathrm{~min}$ followed by 30 cycles of denaturation $\left(94^{\circ} \mathrm{C}, 30 \mathrm{~s}\right)$, annealing $\left(55^{\circ} \mathrm{C}, 30 \mathrm{~s}\right)$ and elongation $\left(72^{\circ} \mathrm{C}, 1 \mathrm{~min}\right)$. We used two successive PCR to have sufficient amplification. These conditions yielded a 1166 bp product which was subcloned into pGEM5zf(+) (Promega) and plasmid DNA was prepared for insert sequencing. Nucleotide sequencing was performed using the Sanger dideoxynucleotide chain-termination method on denatured double-stranded plasmid templates 
using T7 DNA polymerase (Pharmacia kit). To determine the exact sequence of the human heart 5-HT 4 cDNA, we performed three independent PCRs on three independent preparations of poly(A) ${ }^{+}$RNA. To confirm the sequence of the 5 ' part of the receptor around the ATG codon, we performed a PCR reaction using the following primers: ON3 (Patent, sequence 1, position 21-41): 5'-GGTTGGAAGGAGGAGGATGCT-3', in the 5' non-coding sequence, and ON4 (Patent, sequence 1, position 699-721): 5'-GAGGAGAAACGGGATGTAGAAGG-3', in the middle of the receptor sequence. To confirm the sequence of the $3^{\prime}$ part of the receptor around the stop codon, we performed a PCR reaction using the following primers ON5 (Patent, sequence 1, position 1133-1150): 5'-CCCTGTTCAACCACAACC-3' in the middle of the receptor sequence and ON6 (Patent, sequence 1, position 1262-1285): 5'AAAGGCAAGCCACGTCTTCAATCA-3' in the 3' noncoding region of the rat receptor. The PCR conditions with Taq DNA polymerase (Eurobio) were those described here above. The amplified fragments (701 bp and $153 \mathrm{bp}$, respectively) were subcloned and sequenced. cDNA encoding human brain 5-HT4S receptor was cloned by RT PCR on total human brain poly $(\mathrm{A})^{+}$ RNA (Clontech) by following the same procedures as described above.

\section{Transfection of LLC-PK1 and COS-7 cells}

Human 5-HT 4 cDNA was subcloned into pRK5, a CMV-based expression vector ${ }^{12}$ and introduced into LLC-PK1 cells (a gift from Dr Falk Fahrenholz, Germany) or COS-7 cells by electroporation as described in Ref. ${ }^{8}$

\section{cAMP assays}

Six hours after transfection, cells were incubated overnight in DMEM without FBSd (foetal bovine serum dialysed) with $2 \mu \mathrm{Ci}\left[{ }^{3} \mathrm{H}\right]$-adenine/ml to label the ATP pool and cAMP accumulation was measured as described in Ref. ${ }^{1}$

\section{Membrane preparations and radioligand binding assays}

Membranes were prepared from transiently transfected cells plated on $15 \mathrm{~cm}$ dishes and grown in DMEM with 10\% FBSd for $6 \mathrm{~h}$ and $20 \mathrm{~h}$ in DMEM without FBSd. Radioligand binding studies with $\left[{ }^{3} \mathrm{H}\right]$ GR 113808 were performed as previously described. ${ }^{13}$ Membranes were also prepared from human atrial tissue $(2 \mathrm{~g})$ which was reduced to a powder under nitrogen and homogenized in $20 \mathrm{ml}$ of a buffer containing $50 \mathrm{mM}$ HEPES (pH 7.4), 5 mM EGTA, $1 \mathrm{mM}$ EDTA, 0.32 M sucrose and antiproteases, and homogenized with an Ultra Turrax T25 at 24000 $\mathrm{T} / \mathrm{min}$ for $30 \mathrm{~s}$ at $4^{\circ} \mathrm{C}$. The homogenate was filtered through gauze and centrifuged for $15 \mathrm{~min}$ 
at $14000 \mathrm{xg}$ at $4^{\circ} \mathrm{C}$. The pellet was resuspended in the same buffer and homogenized 10 times with a glass-Teflon pestle at $4^{\circ} \mathrm{C}$. The homogenate was centrifuged at $40000 \mathrm{x} \mathrm{g}$ for $20 \mathrm{~min}$, the membrane pellet was resuspended in $50 \mathrm{mM}$ HEPES $(\mathrm{pH} 7.4)$ and stored at $-80^{\circ} \mathrm{C}$ until used. Radioligand binding studies with $\left[{ }^{3} \mathrm{H}\right] \mathrm{GR} 113808$ were performed as for membranes prepared from transiently transfected cells at $20^{\circ} \mathrm{C}$ for $30 \mathrm{~min}$ in a total volume of $250 \mu 1$ with about $200 \mu \mathrm{g}$ membrane protein.

\section{Data analysis}

Competition and saturation experiments were analyzed by non-linear regression using the computer program LIGAND. ${ }^{14}$ Saturation experiments were also analyzed according to Scatchard. ${ }^{15}$

\section{RESULTS}

\section{Cloning and primary amino acid sequence of a human 5-HT $\mathrm{T}_{4}$ receptor}

We performed RT-PCR experiments with poly $(\mathrm{A})^{+}$RNA purified from human atrium using the primer designed to clone the short form of the receptor $5-\mathrm{HT}_{4} \mathrm{~s}$. The transcript of the 5- $\mathrm{HT}_{4}$ receptor expressed in heart has been reported to be a short form. ${ }^{7}$ The resulting fragment (1166 bp) ligated into the plasmid pGEM was completely sequenced on both strands. We isolated three full-length cDNA fragments, obtained from three independent PCRs, with identical sequences. Sequence analysis revealed one long open reading frame of 387 amino acids. A similar strategy was used to isolate from human brain poly (A) ${ }^{+}$RNA, cDNA fragments coding for human $5-\mathrm{HT}_{4}$ receptor. Identical nucleotide sequences were found in clones obtained from the human heart and brain. The amino acid sequence of this human $5-\mathrm{HT}_{4}$ receptor was markedly homologous to that of the rat 5-HT4S (Fig. 1). A difference of 111 nucleotides was found between human and rat cDNA leading to 24 differences in the amino acid sequence (Fig. 1). Compared with rat 5-HT4 receptor, the N-glycosylated sites and most of the consensus amino acids and sequences of the biogenic amine receptors were conserved, ${ }^{16}$ including the aspartates in transmembrane domains [(TMD)-II (D66) and TMD-III (D100)] engaged in coupling to $G$ proteins and ligand binding respectively, the cysteines of the extracellular loops e1 and e2 likely engaged in a disulfide bridge, the DRY sequence at the Nterminus of the second intracellular loop i2, which is important for activation of G proteins, ${ }^{17}$ the prolines in TMD-V, TMD-VI and TMD-VII, and a cysteine (C328) which is a potential palmitoylation site. ${ }^{18}$ As for rat 5-HT $4 \mathrm{~S}$ receptor, human $5-\mathrm{HT}_{4 \mathrm{~S}}$ receptor has three potential 
phosphorylation sites for protein kinase $\mathrm{C}$ (PKC) but no putative site for protein kinase A (PKA). The carboxy-terminus of the human 5- $\mathrm{HT}_{4 \mathrm{~S}}$ receptor $\left(\mathrm{h} 5-\mathrm{HT}_{4 \mathrm{~S}}\right)$ has five serine and six threonine residues located after a pair of acidic amino acids in a 57 amino acid peptide of the extreme carboxy-terminus. These residues are putative phosphorylation $\operatorname{sites}^{19}$ for the family of cAMP-independent G-protein-coupled receptor kinases (GRKs). ${ }^{20}$

\section{Comparison between pharmacological properties of human and rat 5-HT 4 receptors}

Transient transfection of LLC-PK1 cells or COS-7 cells with cDNA encoding the h5- $\mathrm{HT}_{4 \mathrm{~S}}$ receptor or the short form of rat $5-\mathrm{HT}_{4}\left(\mathrm{r} 5-\mathrm{HT}_{4 \mathrm{~S}}\right)$ resulted in the appearance of a single class of high-affinity, saturable binding sites for $\left[{ }^{3} \mathrm{H}\right] \mathrm{GR} 113808$, giving a Hill coefficient not different from $1\left(\mathrm{~K}_{\mathrm{d}}=0.082+/-0.02 \mathrm{nM}\right.$ and $0.089+/-0.016 \mathrm{nM}(\mathrm{n}=6)$, respectively, at $20^{\circ} \mathrm{C}$; Fig. 2A). No detectable binding was found in mock transfected LLC-PK1 or COS-7 cells. In order to compare the pharmacological properties of the rat and human receptors, we measured the affinities of $5-\mathrm{HT}_{4}$ receptor agonists and $5-\mathrm{HT}_{4}$ receptor antagonists by displacement experiments. All the displacement curves were monophasic, giving a Hill coefficient not different from 1. A significant correlation $(r=0.99)$ was found between the affinities of the six agonists and five antagonists tested on the rat and human 5-HT4s receptors (Fig. 2B).

As expected, stimulation of human 5-HT4S receptors transfected into LLC-PK1 or COS7 cells resulted in a dose-dependent accumulation of cAMP. EC $\mathrm{E}_{50}$ and PKi values were measured in transiently transfected LLC-PK1 cells expressing human $5-\mathrm{HT}_{4 \mathrm{~S}}$ or rat $5-\mathrm{HT}_{4 \mathrm{~S}}$ receptors as described above. As reported in Table 1, none of the substitutions observed between rat and human $5-\mathrm{HT}_{4}$ receptors modify the pharmacology or the transduction properties of one receptor compared to the other.

\section{Are benzamides full or partial agonists because of a species or coupling difference?}

One of the main pharmacological differences between the $5-\mathrm{HT}_{4}$ receptors described in different tissues or species is that benzamides are either full (in mouse colliculi neurons) ${ }^{11}$ or partial agonists (in mouse hippocampal membranes or human heart). ${ }^{3,9}$ Figure $3 \mathrm{~A}$ is an illustration of our previous results showing the partial agonism of renzapride on human heart $5-\mathrm{HT}_{4}$ receptors, compared with the full agonist behavior of this drug in mouse colliculi neurons. ${ }^{1,10,11}$ It was of interest, therefore, to examine why renzapride had such a poor efficacy on human heart 5- $\mathrm{HT}_{4}$ receptors. Saturation binding with $\left[{ }^{3} \mathrm{H}\right] \mathrm{GR} 113808$ identified $8+/-2$

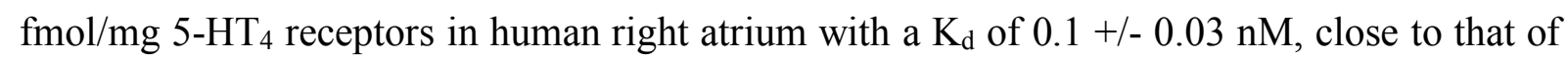
the cloned human 5-HT4S receptors (not shown). In COS-7 cells expressing a low density of 
receptors, renzapride acted indeed as a partial agonist. However, when tested on cells expressing an increasing number of receptors, the partial agonism of renzapride was progressively suppressed (Fig. 3B, C).According to the classical pharmacological ${ }^{21}$ and operational models, ${ }^{22}$ if one supposes that the agonist $(\mathrm{H})$ interacts with the receptors $(\mathrm{R})$ following a simple mass action kinetic:

$$
\mathrm{RH}=\mathrm{RT} \frac{\mathrm{H}}{\mathrm{Kd}+\mathrm{H}}
$$

and that a chain of hyperbolic coupling steps (including the interaction of $\mathrm{RH}$ with $\mathrm{G}$ proteins),

$$
\mathrm{RH}+\mathrm{G} \longrightarrow \mathrm{RHG} \quad(\text { Equation 2) }
$$

occurs between the formation of RH and the final response. Then, the final response is expected to be a hyperbolic function of the ligand concentration, as generally observed. Therefore the final response (E) (cAMP production) is also a hyperbolic function of RH:

$$
\mathrm{E}=\mathrm{ET} \frac{\mathrm{RH}}{\mathrm{Ct}+\mathrm{RH}}
$$

It is possible to determine the coupling constant $\left(\mathrm{C}_{\mathrm{t}}\right)$ for 5 -HT and renzapride as well as maximal cAMP which can be produced (ET) when RH is very high compared to $\mathrm{C}_{\mathrm{t}}$. Plotting E as a function of E/RH (Fig. 4) gives a straight line, the slope of which is equal to $\mathrm{C}_{\mathrm{t}}$. ET is equal to $\mathrm{E}$ when $\mathrm{E} / \mathrm{RH}=0$. In COS-7 cells, the coupling constant for 5-HT was twice as high as the coupling constant for renzapride (135 +/- 9 and $70+/-3 \mathrm{fmol} / \mathrm{mg}$, respectively). As indicated in Fig. 4A, ET values were identical for 5-HT and renzapride. This implied that at high receptor density, renzapride was a full agonist. Interestingly in LLC-PK1, a similar analysis also gave a 2-fold difference between $C_{t}$ values for 5 -HT and renzapride $(46+/-4$ and $26+/-2 \mathrm{fmol} / \mathrm{mg}$, respectively) and again similar values of ET for the two drugs.

\section{DISCUSSION}

We have isolated a cDNA encoding $5-\mathrm{HT}_{4 \mathrm{~S}}$ receptor by RT-PCR on poly $(\mathrm{A})^{+} \mathrm{RNA}$ from both human heart and brain using specific primers from the rat $5-\mathrm{HT}_{4 \mathrm{~S}} \mathrm{cDNA}$ sequence ${ }^{7} \underline{7}$ The nucleotide sequences of the clones were identical, indicating that the same 5- $\mathrm{HT}_{4}$ receptor is expressed in both heart and brain. The human 5-HT 4 receptor that we cloned was also highly homologous to those previously cloned from rat and mouse brain. ${ }^{7,8}$ Although not formal proof, this suggests that only one gene coding for $5-\mathrm{HT}_{4}$ receptors exists in different species.

None of the 24 amino acid substitutions observed between rat and human $5-\mathrm{HT}_{4}$ receptors are at a position likely to modify the pharmacology or the transduction properties of 
the receptor. However, a single amino acid substitution may drastically modify the binding properties or the coupling properties of $\mathrm{G}$ protein-coupled receptors. The now classical example

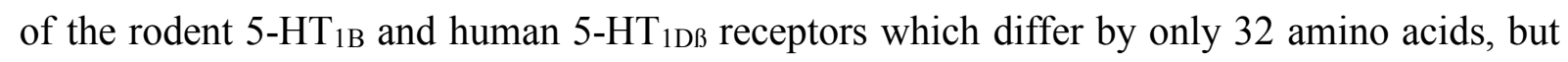
which recognized $\beta$-adrenergic antagonists with high and low affinity, respectively, should encourage us not to make rapid conclusions. In this the latter an asparagine in the TMD-VII of rodent which is necessary for high affinity for $\beta_{2}$-adrenergic antagonists is substituted by threonine in the human $5-\mathrm{HT}_{1 \mathrm{D \beta} .}{ }^{23}$ Human as well as rat and mouse 5- $\mathrm{HT}_{4}$ contained no potential PKA phosphorylation site, consistent with the absence of cAMP-mediated desensitization of 5- $\mathrm{HT}_{4}$ receptors. In colliculi neurons and rat oesophagus, $5-\mathrm{HT}_{4}$ receptors are rapidly and potently desensitized by homologous desensitization. ${ }^{24}$ In contrast, in human heart, 5-HT4-mediated responses do not desensitize in a notable manner. ${ }^{25}$ Comparison of the primary sequences of $5-\mathrm{HT}_{4 \mathrm{~S}}$ receptors expressed in colliculi neurons and human heart reveal no differences in the putative phosphorylated sites for GRK. It has been proposed that GRK are acidotropic kinases preferring acidic amino acids in proximity of putative phosphorylation sites. The $\beta_{2}$-adrenergic receptor rhodopsin, an $\mathrm{N}$-formyl peptide receptor, as well as the $\alpha_{2}$-adrenergic receptor have a pair of acidic residues, at the N-terminal side of the most aminoterminal phosphorylated residue, such as ED, DE or EE. ${ }^{19}$ In rat, mouse and human $5-\mathrm{HT}_{4 \mathrm{~S}}$ receptors the acidic doublet $\mathrm{DE}$ is present at position 331 and 332 followed by 11 serine or threonine residues, which are susceptible to phosphorylation by a family of GRK proteins ${ }^{20}$ In the long form of mouse and rat 5- $\mathrm{HT}_{4}$ receptors $\left(5-\mathrm{HT}_{4 \mathrm{~L}}\right)$, another acidic doublet (ED) is present at positions 396 and 397 followed by three and four serine residues respectively, including the C-terminal residue. This could explain preliminary results indicating that $5-\mathrm{HT}_{4 \mathrm{~L}}$ is more susceptible to desensitization than is $5-\mathrm{HT}_{4 \mathrm{~S}}{ }^{26}$ Both the long and the short forms of 5-HT 4 receptors are present in neurons, ${ }^{8}$ whereas only the short form seems to be present in human heart $\underline{7}$ (we were unable to amplify the long form by RT-PCR using poly (A) ${ }^{+}$RNA prepared from human atrium). This may explain why homologous desensitization is more efficient in neurons.We have studied the question of the partial agonism of benzamides on different preparations expressing $5-\mathrm{HT}_{4}$ receptors. ${ }^{3}$ When transfected into LLC-PK1 cells and COS-7 cells the coupling constant $\left(\mathrm{C}_{\mathrm{t}}\right)$ showed that in both cell lines the coupling capacity of the renzapride $/ 5-\mathrm{HT}_{4}$ receptor complex was two-fold lower than that of the 5-HT/5-HT 4 receptor complex. However, in both cell lines it is clear that at high receptor density renzapride and 5-HT produce the same maximal cAMP accumulation (ET). It is thus likely that the partial agonism of renzapride in some tissues, and especially in heart, is due to a low receptor 
expression level. We measured the level of $5-\mathrm{HT}_{4}$ receptors in human atrium as $8+/-2 \mathrm{fmol} / \mathrm{mg}$ protein.

The fact that a partial agonist behaves as a full agonist when receptor density is increased is consistent with the classical models of pharmacology but has not always been found. We previously reported that when $5-\mathrm{HT}_{1 \mathrm{~A}}$ receptors were transfected into $\mathrm{NIH} 3 \mathrm{~T} 3$ cells, a partial

agonist remained a partial agonist whatever the receptor density. ${ }^{27}$ Further studies are required to explain the nature of this difference.

\section{CONCLUSION}

We have cloned the human $5-\mathrm{HT}_{4 \mathrm{~S}}$ receptor from brain and heart. The same nucleotidic sequences were found in both tissues. None of the 24 residue substitutions observed between rat and human $5-\mathrm{HT}_{4 \mathrm{~S}}$ receptors induced any differences in the pharmacological profile, established by testing the characteristics of classical $5-\mathrm{HT}_{4}$ agonists and antagonists. The present study clearly shows that the efficacy of renzapride relative to that 5-HT was dependent on the receptor density and not on receptor structure. The coupling efficiency of renzapride was two-fold lower than that of 5-HT in two cell lines, but increasing the receptor density suppressed the partial agonist effect of renzapride.

\section{ACKNOWLEDGEMENTS}

We are grateful to Dr Christophe Gerald (Synaptic Pharmaceutical Corporation, Paramus NJ, USA) for the generous gift of rat 5-HT $4 \mathrm{~L}$ and 5-HT4S cDNA. For helpful comments and valuable discussions, we thank Drs L. Fagni and J.-P. Pin. Mrs A.L. Turner-Madeuf and M. Passama are acknowledged for their help in language revision and preparation of figures respectively. This work was supported by grants from the Centre National de la Recherche Scientifique Laboratoires Fournier-Debat (Daix, France) and the Fondation pour la Recherche Médicale. 


\section{REFERENCES}

1. Dumuis A, Bouhelal R, Sebben M et al. Mol. Pharmacol. 34, 880-887 (1988).

2. Eglen R, Wong EHF, Dumuis A et al. Trends Pharmacol Sci 16, 391-398 (1995).

3. Bockaert J, Fozard J, Dumuis A et al. Trends Pharmacol Sci 13, 141-145 (1992).

4. Letty S, Child R, Pantaloni A et al. Neuropharmacology 36, 681-687 (1997).

5. Marchetti-Gauthier E, Roman FS, Dumuis A et al. Neuropharmacology 36, 697-706 (1997).

6. Hegde S and Eglen RM. FASEB J 10, 1-10 (1996).

7. Gerald C, Adham N, Kao H-T et al. EMBO J 14, 2806-2815 (1995).

8. Claeysen S, Sebben M, Journot L et al. FEBS Lett 398, 19-25 (1996).

9. Kaumann AJ, Sanders L, Brown AM et al. Naunyn-Schmiedeberg's Arch Pharmacol 344, 150-159 (1991)

10. Ouadid H, Seguin J, Dumuis A et al. Mol Pharmacol 41, 346-351 (1992).

11. Dumuis A, Sebben M and Bockaert J. Naunyn-Schmiedeberg's Arch Pharmacol 340, 403-410 (1989).

12. Schall TJ, Lewis M, Koller KJ et al. Cell 61, 361-370 (1990).

13. Ansanay H, Sebben M, Bockaert J et al. Eur J Pharmacol 298, 165-174 (1996).

14. Munson PJ and Rodbard D. Anal Biochem 107, 220-239 (1980).

15. Waeber C, Sebben M, Grossman C et al. NeuroReport 4, 1239-1242 (1993).

16. Bockaert J. Curr Opin Neurobiol 1, 32-42 (1991).

17. Oliviera L, Paiva ACM, Sander C et al. Trends Pharmacol Sci 15, 170-172 (1994).

18. O'Dowd BF, Hnatowitch M, Caron MG et al. J Biol Chem 264, 7564-7569 (1989).

19. Fredericks ZL, Pitcher JA and Lefkowitz RJ. J Biol Chem 271, 13796-13803 (1996).

20. Premont RT, Inglese J and Lefkowitz RJ. FASEB J 9, 175-182 (1995).

21. Kenakin TP and Morgan PH. Mol Pharmacol 1, 445-451 (1989).

22. Leff P. Trends Pharmacol Sci 9, 935-937 (1988).

23. Oksenberg D, Marsters SA, O'Dowd BF et al. Nature 360, 161-163 (1992).

24. Ansanay H, Sebben M, Bockaert J et al. Mol Pharmacol 42, 808-816 (1992).

25. Kaumann AJ and Sanders L. Naunyn-Schmiedeberg's Arch Pharmacol 349, 331-337 (1994).

26. Adhams N, Gerald C, Vaysse PJ-J et al. Soc Neurosci Abstr 21, 773 (1995).

27. Varrault A, Journot L, Audigier Y et al. Mol Pharmacol 41, 999-1007 (1992).

28. Cheng Y and Prussoff H. Biochem Pharmacol 22, 3099-3108 (1973). 


\begin{tabular}{|c|c|c|c|c|c|}
\hline \multirow[t]{3}{*}{ Compound } & & \multicolumn{2}{|c|}{ Binding } & \multicolumn{2}{|c|}{ Adenylyl cyclase stimulation } \\
\hline & & h5-HT $_{4 \mathrm{~S}}$ & $\mathrm{r}^{2}-\mathrm{HT}_{4} \mathrm{~S}$ & h5-HT $_{4 \mathrm{~s}}$ & $\mathrm{r5}-\mathrm{HT}_{4 \mathrm{~s}}$ \\
\hline & $\mathbf{n}^{\circ}$ & $\mathrm{pK}_{\mathrm{d}}$ & $\mathrm{pK}_{\mathrm{d}}$ & $\mathrm{pEC}_{50}$ & pEC50 \\
\hline \multicolumn{6}{|l|}{ Agonists } \\
\hline 5-HT & 1 & $7.25 \pm 0.12$ & $7.41 \pm 0.14$ & $8.05 \pm 0.28$ & $8.58 \pm 0.15$ \\
\hline Bimu 8 & 2 & $7.34 \pm 0.16$ & $7.72 \pm 0.18$ & $7.88 \pm 0.15$ & $7.63 \pm 0.22$ \\
\hline Renzapride & 3 & $6.76 \pm 0.14$ & $6.95 \pm 0.20$ & $7.55 \pm 0.23$ & $7.35 \pm 0.19$ \\
\hline Zacopride & 4 & $6.55 \pm 0.09$ & $6.73 \pm 0.12$ & $6.72 \pm 0.17$ & $6.87 \pm 0.28$ \\
\hline 5-MeOt & 5 & $6.81 \pm 0.18$ & $6.91 \pm 0.10$ & $7.84 \pm(0.12$ & $8.61 \pm 0.34$ \\
\hline \multirow[t]{2}{*}{$5-\mathrm{CT}$} & 6 & $4.62 \pm 0.25$ & $5.04 \pm 0.21$ & $5.56 \pm 0.23$ & $5.67 \pm 0.25$ \\
\hline & & $\mathrm{pK}_{\mathrm{d}}$ & $\mathrm{pK}_{\mathrm{d}}$ & $\mathrm{pK}_{\mathrm{i}}$ & $\mathrm{pKi}$ \\
\hline \multicolumn{6}{|l|}{ Antagonists } \\
\hline DAU 6285 & 7 & $7.98 \pm 0.15$ & $8.27 \pm 0.17$ & $7.73 \pm 0.20$ & $7.65 \pm 0.26$ \\
\hline GR 113808 & 8 & $10.03 \pm 0.22$ & $10.51 \pm 0.28$ & $10.56 \pm 0.36$ & $10.68 \pm 0.19$ \\
\hline GR 125487 & 9 & $10.66 \pm 0.26$ & $11.05 \pm 0.33$ & $12.06 \pm 0.27$ & $12.04 \pm 0.16$ \\
\hline SB 207266 & 10 & $9.52 \pm 0.28$ & $9.32 \pm 0.22$ & $10.85 \pm 0.35$ & $11.25 \pm 0.30$ \\
\hline RS 100235 & 11 & $12.24 \pm 0.24$ & $12.40 \pm 0.21$ & $12.20 \pm 0.21$ & $12.32 \pm 0.12$ \\
\hline
\end{tabular}

\section{Table 1}

Pharmacological profile of the human $5-\mathrm{HT}_{4 \mathrm{~S}}$ receptor. Comparison with the rat $5-\mathrm{HT}_{4 \mathrm{~S}}$ receptor previously cloned by Gerald and co-workers. ${ }^{7}$

cAMP production was measured as described in Materials and Methods in transiently transfected LLC-PK1 cells expressing human 5-HT4S or rat 5- $\mathrm{HT}_{4 \mathrm{~S}}$ receptors. $\mathrm{EC}_{50}$ values were determined graphically and corresponded to the concentrations of agonists required to obtain a half-maximal stimulation of adenylyl cyclase. Data are expressed as means \pm s.e.m. in duplicate determinations performed at least in four separate transfected LLC-PK1 cell cultures. For the antagonists, $\mathrm{Ki}$ values were calculated from the concentration of the drugs that reversed $50 \%$ the stimulation induced by $5-\mathrm{HT}(0.1 \mu \mathrm{M})$. Data are expressed as means \pm s.e.m. of $3-5$ separate transfected LLC-PK1 cell cultures performed in duplicate.

Binding data correspond to the affinities of various compounds that compete for $\left[{ }^{3} \mathrm{H}\right] \mathrm{GR}$ 113808 binding in transfected LLC-PK1 cell membrane (15 mg) expressing $120 \pm 22$ and 145 $\pm 28 \mathrm{fmol} / \mathrm{mg}$ protein of human $5-\mathrm{HT}_{4 \mathrm{~S}}$ or rat $5-\mathrm{HT}_{4 \mathrm{~S}}$ receptors respectively. $\mathrm{IC}_{50}$ values correspond to a displacement of $50 \%$ of $\left[{ }^{3} \mathrm{H}\right] \mathrm{GR} 113808$ binding determined experimentally on membrane harvested from transiently transfected LLC-PK1 cells as described in Materials and Methods and converted to $\mathrm{K}_{d}$ values according to the equation of Cheng and Prusoff. Data are expressed as means \pm s.e.m. of at least four separate experiments. The concentration of $\left[{ }^{3} \mathrm{H}\right] \mathrm{GR}$ 113808 used was $0.25 \mathrm{nM}$. Non-specific binding, determined by addition of $50 \mu \mathrm{M} 5$-HT, represented only $10 \pm 3 \%$ of total binding. 


\section{FIGURE LEGENDS}

\section{Figure 1}

Nucleotide sequence of a human $5-\mathrm{HT}_{4 \mathrm{~S}}$ receptor: comparison with the rat $5-\mathrm{HT}_{4 \mathrm{~S}}$ receptor. The receptor was sequenced on both strands from ON1 (position 1) to the end of ON2 (position 1166). The seven putative transmembrane domains are boxed and numbered (I-VII). Changes in amino acids in human vs rat receptor are shaded and rat amino acids are indicated below. $\bullet$, sites of potential N-linked glycosylation. $\bullet$, site of potential palmitoylation. consensus sites for phosphorylation by protein kinase $\mathrm{C},{ }^{*}$, putative sites for G-protein coupled receptor kinases (GRK), $\star$, terminal stop codon.

\section{Figure 2}

Pharmacological characteristics of a human 5- $\mathrm{HT}_{4 \mathrm{~S}}$ receptor: comparison with the rat 5- $\mathrm{HT}_{4 \mathrm{~S}}$ receptor. (A) Characteristics of $\left[{ }^{3} \mathrm{H}\right] \mathrm{GR} 113808$ binding in membranes $(20 \mu \mathrm{g}$ of protein in a total volume of $250 \mu \mathrm{l}$ ) prepared from transiently transfected LLC-PK1 cells, electroporated with $1 \mu \mathrm{g}$ human or rat $5-\mathrm{HT}_{4 \mathrm{~S}}$ receptor cDNA/10 $\underline{6}$ cells and incubated with eight different concentrations of $\left[{ }^{3} \mathrm{H}\right] \mathrm{GR} 113808(0.01-1.5 \mathrm{nM})$ for $30 \mathrm{~min}$ at $20^{\circ} \mathrm{C}$. The presented typical experiment is representative of three separate experiments. Each assay was performed in triplicate. Inset: Scatchard analysis of saturation experiments of $\left[{ }^{3} \mathrm{H}\right] \mathrm{GR} 113808$ binding to human and rat 5- $\mathrm{HT}_{4 \mathrm{~S}}$ receptors. (B) Correlation between the affinities of $115-\mathrm{HT}_{4}-$ active drugs (six agonists and five antagonists) for $\left[{ }^{3} \mathrm{H}\right] \mathrm{GR} 113808$ binding sites of cells (LLCPK1) transfected with the cloned human 5- $\mathrm{HT}_{4 \mathrm{~S}}$ receptor or transfected with the cloned rat 5$\mathrm{HT}_{4 \mathrm{~S}}$ receptor. Binding data correspond to competition of $\left[{ }^{3} \mathrm{H}\right] \mathrm{GR} 113808(0.25 \mathrm{nM})$ binding to membranes $(20 \mu \mathrm{g})$ of LLC-PK1 cells transiently expressing human 5-HT4s receptor (120 $+/-18 \mathrm{fmol} / \mathrm{mg}$ protein) or rat $5-\mathrm{HT}_{4 \mathrm{~s}}$ receptor $\left(105+/-21 \mathrm{fmol} / \mathrm{mg}\right.$ protein). $\mathrm{IC}_{50}$ values required to displace $50 \%$ of $\left[{ }^{3} \mathrm{H}\right] \mathrm{GR} 113808$ binding were determined experimentally and converted to $\mathrm{K}_{d}$ values according to the Cheng-Prussoff equation: $28 \mathrm{~K}_{d}=\mathrm{IC}_{50} /\left(1+\mathrm{S} / \mathrm{K}_{\mathrm{dS}}\right)$ where $\mathrm{S}$ is $\left[{ }^{3} \mathrm{H}\right] \mathrm{GR} 113808$ concentration $(0.25 \mathrm{nM})$ and $\mathrm{K}_{\mathrm{dS}}$ is the equilibrium constant of [ $\left.{ }^{3} \mathrm{H}\right]$ GR 113808 . The $\mathrm{x}$ axis shows $\mathrm{pK}_{\mathrm{d}}$ values for $115-\mathrm{HT}_{4}$-active drugs for the cloned human 5-HT $4 \mathrm{~S}$ and the y axis shows the $\mathrm{pK}_{\mathrm{d}}$ values for cloned rat 5- $\mathrm{HT}_{4 \mathrm{~S}}$ receptors. All values are taken from Table 1. The numbers in Fig. 2B correspond to the numbers in Table 1. 


\section{Figure 3}

Effect of the receptor densities on the dose-response curves for 5-HT and renzapride on endogenous 5- $\mathrm{HT}_{4}$ receptors in human heart and on human $5-\mathrm{HT}_{4 \mathrm{~S}}$ receptor transiently expressed in COS-7 cells. (A) Effect of 5-HT and renzapride on increasing $\mathrm{Ca}^{2+}$ current $(\mathrm{Ca})$ in human cardiomyocytes (data from Ref. ${ }^{10}$ ). (B) Effect of human 5-HT4s receptor density on the dose-response curves of 5-HT in COS-7 cells. The densities of 5-HT 4 receptors were 10 , 30, 36, 123, 258 and $311 \mathrm{fmol} / \mathrm{mg}$ protein in COS-cells transfected with 25, 50, 100, 500 and 1000 ng of cDNA, respectively. (C) Effect of human 5-HT4S receptor density on the doseresponse curves of renzapride in COS-7 cells. The expression levels of 5- $\mathrm{HT}_{4}$ receptors were the same as in (B). cAMP productions measured at different concentrations of drugs are expressed as the percentage over basal cAMP produced in the mock-transfected cells (control). The percentage conversion of $\left[{ }^{3} \mathrm{H}\right]$-ATP to $\left[{ }^{3} \mathrm{H}\right]$-cAMP in control was $0.158+/-0.04$. In (B) and $(\mathrm{C})$ results are mean $+/$ - standard error of triplicate determinations from a typical experiment.

\section{Figure 4}

Determination of the coupling constant $\left(\mathrm{C}_{\mathrm{t}}\right)$ of 5-HT and renzapride and their maximal efficacy (ET). (A) cAMP production (E) for maximal concentrations of 5-HT and renzapride $(>1 \mu \mathrm{M})$ was measured at different concentrations of human 5-HT4S receptor $(\mathrm{RH})$ expressed in COS-7 cells. E was plotted as a function of (E/RH). For COS-7 cells, data are taken from Fig. 3. (B) cAMP production for maximal concentrations of 5-HT and renzapride $(>1 \mu \mathrm{M})$ was measured at different concentrations of human $5-\mathrm{HT}_{4 \mathrm{~S}}$ receptor (HR) expressed in LLC-PK1 cells. The expression level of human $5-\mathrm{HT}_{4 \mathrm{~S}}$ receptors was $11,18,25,55,39,56$ and $77 \mathrm{fmol} / \mathrm{mg}$ protein in LLC-PK1 cells transfected with 50, 100, 200, 400, 500, 800 and $1000 \mathrm{ng}$ of human 5-HT4S receptor cDNA, respectively. The presented typical experiment is representative of three separate experiments. E plotted as a function of E/RH gives a straight line, the slope of which is $\mathrm{C}_{\mathrm{t}}$. $\mathrm{E}_{\mathrm{t}}$ is equal to $\mathrm{E}$ when $\mathrm{E} / \mathrm{RH}=0$. The coupling constant for 5-HT in COS-7 cells was 2fold higher than that for renzapride $(135+/-9$ and $70+/-3 \mathrm{fmol} / \mathrm{mg}$, respectively). As indicated in Fig. 4, $\mathrm{E}_{\mathrm{t}}$ was identical for 5-HT and renzapride. This means that at high receptor density, renzapride is a full agonist. Interestingly, in LLCPK1 cells, a similar analysis gave also a 2-fold difference between the values of $C_{t}$ for 5 -HT and renzapride $(46+/-4$ and $26+/-2 \mathrm{fmol} / \mathrm{mg}$ protein, respectively) and again a similar $\mathrm{E}_{\mathrm{t}}$ for the two drugs. 


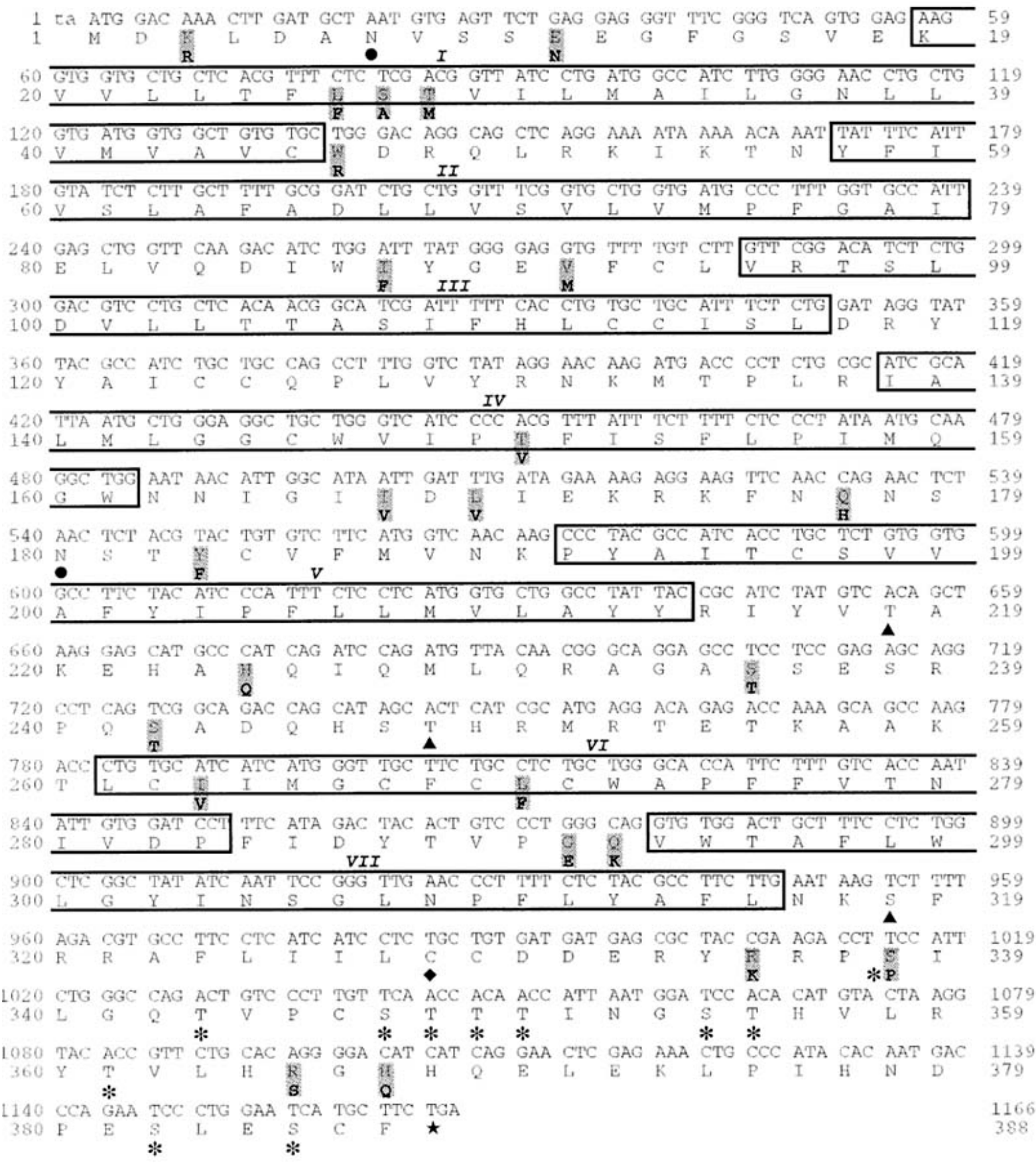

Figure 1 

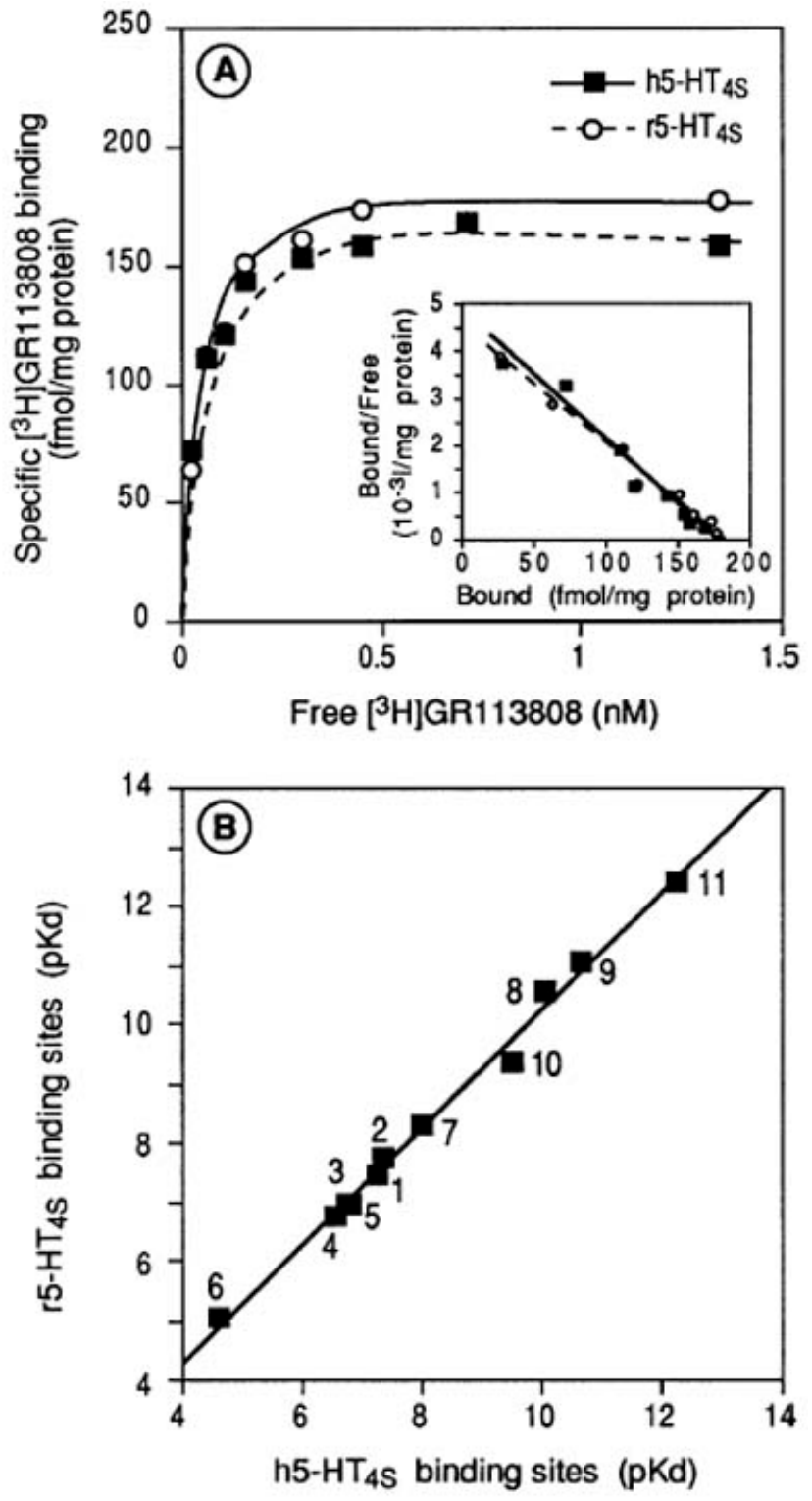

Figure 2 

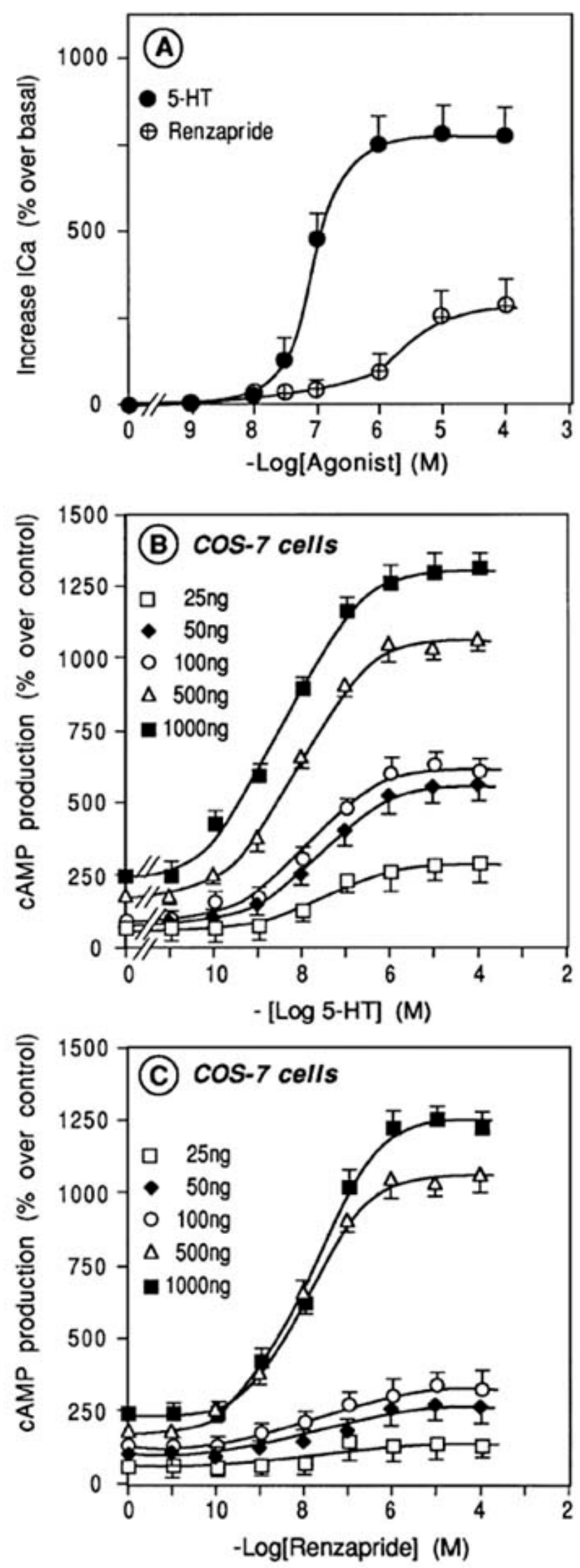

Figure 3 

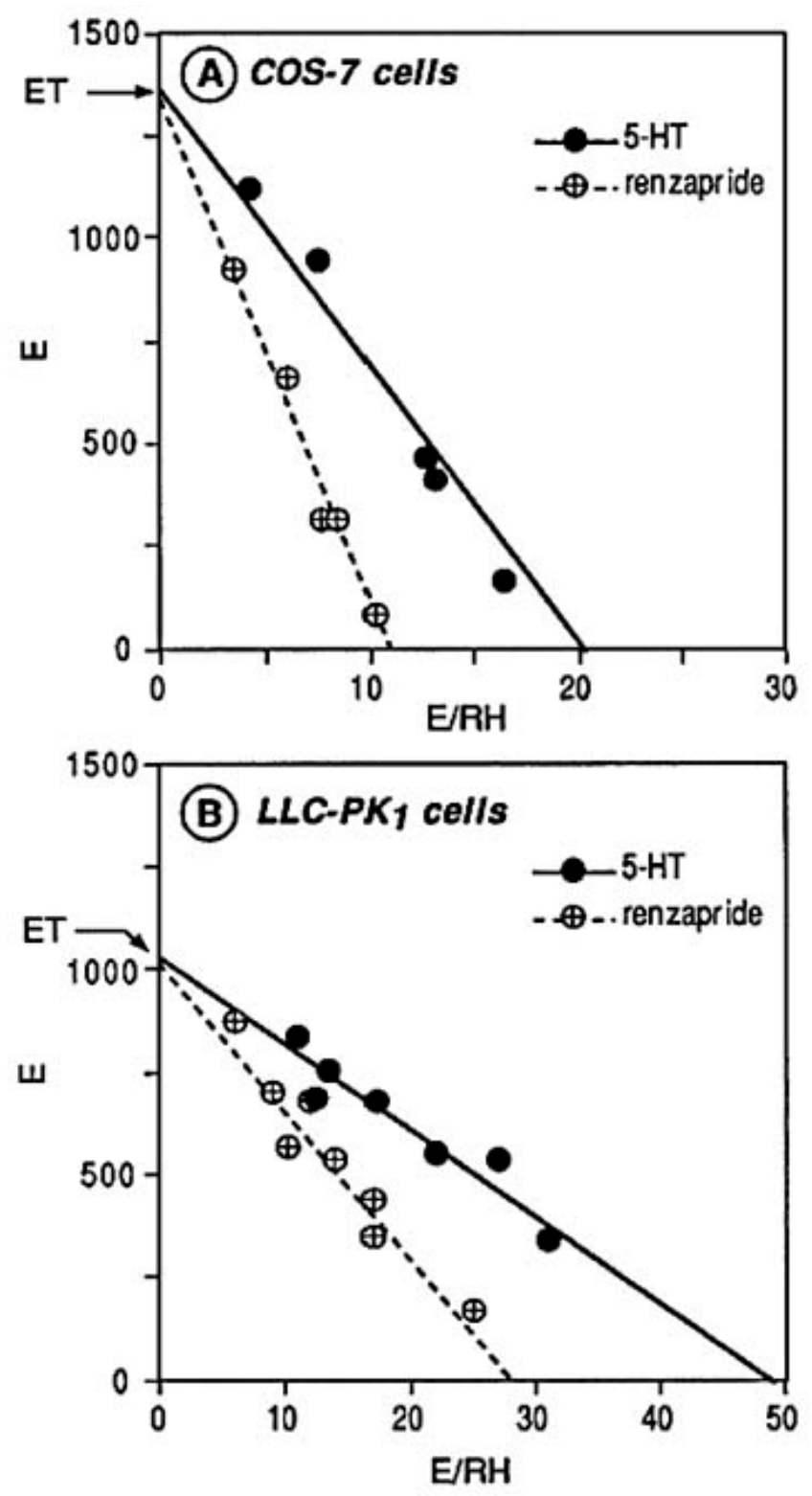

Figure 4 